\title{
PENDIDIKAN TOLERANSI BERAGAMA UNTUK HUMANISME ISLAM DI INDONESIA
}

\author{
Nur Said \\ STAIN Kudus, Jawa Tengah, Indonesia \\ nursaid@stainkudus.ac.id
}

\begin{abstract}
RELIGIOUS TOLERANCE EDUCATION FOR ISLAMIC HUMANISM IN INDONESIA. This paper is organized as a response to the turmoil of religious conflicts in recent years in Indonesia. Islamic educational institution has the responsibility for the actual history of Islam so this nation can be a tolerant or intolerant nation. This study focused on: (1) Rediscovering Islamic educational orientation in Indonesia; (2) Analysing the causes of Islamic education in the perspective of theological insight of religious tolerance; (3) Offering the core values in Islamic education that are relevant for the development of Islamic humanism education in Indonesia. The research used philosophical and historical approaches because it involved a critical study and Islamic intellectual history in Indonesia. The findings were that Islamic education needs to put the religious humanism as core values in its main orientation. While the education problems related to its goals, contents, methods and evaluation showed that the tendency highlighting aspects of sectoral-fiqhiyah was more than robbaniyyah universal aspect. It is necessary to have reorientation of Islamic education which take priority on morals including moral values of religious tolerance over figh like the treatises message of Prophet as a complement of humanism morals in people's lives.
\end{abstract}

Keywords: Islamic education, religious tolerance, Islamic humanism 


\begin{abstract}
Abstrak
PENDIDIKAN TOLERANSI BERAGAMA UNTUK HUMANISME ISLAM DI INDONESI. Tujuan dari penulisan ini memberikan respon atas gejolak konflik bernuansa agama beberapa tahun terakhir di Indonesia. Institusi pendidikan Islam memiliki tanggung jawab atas historisitas Islam aktual untuk menjadi bangsa yang toleran atau intoleran. Maka fokus kajian ini ada tiga hal: (1) Menemukan kembali orientasi pendidikan Islam di Indonesia; (2) Mengurai akar persoalan pendidikan Islam dalam perspektif wawasan teologi toleransi beragama; (3) Menawarkan nilai-nilai inti yang relevan untuk pengembangan pendidikan humanisme Islam Indonesia. Pendekatan yang digunakan adalah folosofis dan historis karena menyangkat telaah kritis dan sejarah intelektualisme Islam di Indonesia. Hasil dari kajian ini bahwa pendidikan Islam perlu meletakkan humanisme religius sebagai landasan nilai dalam orientasi pengembangannya. Sementara segi problematikanya dari aspek tujuan, isi, metode dan evaluasi menunjukkan bahwa kecenderungan yang menonjolkan aspek sektoral-fiqhiyah di atas aspek universalrobbaniyyah. Maka perlu reorientasi pendidikan Islam dengan semangat mendahulukan akhlak termasuk di dalamnya nilai-nilai moral toleransi beragama di atas fiqh sebagaimana pesan risalah Nabi SAW sebagai penebar moral humanisme dalam kehidupan umat.
\end{abstract}

Kata kunci: Pendidikan Islam, toleransi beragama, humanisme Islam

\title{
A. Pendahuluan
}

Gerakan demonstrasi oleh ribuan sebagian umat Islam di Indonesia pada 4 Nopember 2016 terkait dugaan penistaan agama yang dilakukan oleh Ahok, Gubernur non-aktif DKI Jakarta menunjukkan bahwa masalah agama sangat sensitif dalam memicu kerawanan dan konflik sosial. Namun pada sisi lain menurut Azra (2015) secara substantif seluruh agama besar dunia mengajarkan apa yang disebut sebagai "etika resiprositas" yang sering disebut sebagai "golden rule", yaitu memperlakukan orang lain sebagaimana setiap orang ingin memperlakukan diri sendiri dengan sebaik-baiknya 
Inilah yang kemudian oleh Casanova (1994: 4) dalam kajiannya terhadap agama-agama dalam dunia modern menyimpulkan: "...religon showed its Janus face, as the carrier not only of exclusive, particularist, and primordial identities but also of inclusive, universalist, and transcendeing ones". Elemen agama bisa membawa sesorang atau kelompok umat memiliki semangat ekslusif (intoleran) dan bisa juga inklusif (toleran).

Dalam konteks keindonesiaan gejala intoleransi beragama sudah semakin mengkhawatirkan meskipun hal ini bagian dari dinamika dan konsekwensi dari sebuah bangsa yang majmuk. Konflik bernuansa agama di Poso, Situbondo, Sampit dan Ambon adalah bagian dari sejarah kelam hubungan antar agama di Indonesia (Ismail, 2014: 65-99). Bahkan pada penghujung pertengahan 2015 tentu masih segar dalam ingatan peristiwa Tolikara Papua dimana jamaah umat tertentu yang sedang beribadah dibubarkan oleh sekelompok umat agama lain yang berakibat konflik horizontal. Aksi pembubaran penganut agama manapun yang sedang menjalankan ibadahnya secara telanjang menunjukkan ketiadaan atau kurangnya sikap menghormati "the other religious", penganut agama lain yang berbeda (Azra, 2015; Said, 2005).

Yang lebih memprihatinkan dalam laporan penelitian dari Pusat Pengkajian Islam dan Masyarakat (PPIM) UIN Jakarta seperti dikedepankan oleh Abdallah (2015) tentang «Paham Eksklusif dalam Pendidikan Islam» menunjukkan adanya paham intoleransi keagamaan melalui penyajian buku ajar di sekolah yang kurang mengedepankan aspek dialogis. Berkenaan dengan tema teologis, misalnya, penjelasan tentang apa dan siapa itu kafir, musyrik, dan munafik masih dijelaskan dalam konteks masa Nabi yang seringkali bersifat politis sehingga yang harus diperangi dan dibunuh. Sedangkan tema yang bersifat furu>iyah (berkaitan dengan praktek agama), seperti bacaan salat, jumlah rakaat salat tarawih, dan bacaan kunut, masih mengedepankan satu pandangan tertentu.

Dalam konteks inilah menjadi penting bagi kaum akademikus dan para peneliti untuk menyiapkan alternatif referensi hasil kajian atau penelitian mendalam untuk pengayaan 
wawasan (insights) yang mengedepankan pandangan Islam yang inklusif, toleran, dan menghargai perbedaan yang mampu yang mampu menangkis derasnya paham transnasional yang berbasis pada Wahabisme yang cenderung mengajarkan nilai saling mengkafirkan (takfiriyah).

Kajian ini berusaha menelaah secara mendalam produk dari intelektualisme Islam Indonesia yang bermuara pada peneguhan pendidikan Islam yang berbasis pada teologi toleransi beragama atau menurut Azra (1999: 51-53) disebut sebagai teologi inklusifisme. Dalam pernyataannya disebutnya bahwa:

"Tema sentral teologi inklusivisme adalah pengembangan paham dan kehidupan keagamaan yang inklusif, toleran dan respek terhadap pluralisme keagamaan, sehingga para penganut berbagai aliran keagamaan atau agama-agama dapat hidup berdampingan secara damai (peacefull co-eksistence)."

Tujuan dari kajian ini sebagai respon atas nestapa dunia pendidikan Islam khususnya di Indonesia yang sedang mengalami disorientasi karena terjadi disparitas yang semakin melebar antara Islam ideal sebagai agama yang rahmatan lil aalamiin dengan Islam aktual yang secara nyata menunjukkan ada hak lain. Agar pembahasan menjadi terfokus maka paper hanya terbatas pada pembahasan: (1) Menemukan kembali substansi pendidikan Islam; (2) Mengurai akar persoslan pendidikan Islam dalam perspektif wawasan teologi toleransi beragama di Indonesia; (3) Menggagas pendidikan toleransi beragama dalam perspektif humanisme Islam di Indonesia.

Dalam pelaksanaanya, kajian ini merupakan hasil penelitian literature yang mengedepankan pendekatan filosofis dan sekaligus historis. Pendekatan filosofis, dimaksudkan sebagai upaya pemaknaan dan interpretasi data lebih dominan berdasarkan penalaran logis dari pemaparan data sebagaimana adanya (Barnadib, 1983: 32). Pendekatan ini digunakan atas pertimbangn bahwa data-data yang ada berkaitan dengan teologi toleransi beragama dalam pendidikan Islam menuntut adanya perenungan kefilsafatan sebagai suatu usaha untuk memperoleh pengetahuan dengan langkah-langkah tertentu seperti membatasi masalah, menguji secara rasional yang berkaitan dengan 
kebenaran, mengenal apa yang dikatakan orang lain mengenai masalah-masalah yang bersangkutan, menyarankan suatu hipotesa, menyajikan bahan/ data bukti yang dapat ditemukan dan verifikasi terhadap hasil-hasil penjabaran yang telah dilakukan (Kattsoff, 1992: 34-37). Sementara pendekatan historis dikedepankan untuk menyingkap, menggali dan menelaah serta menganalisis persoalan-persoalan yang menjadi obyek studi ini dari kacamata kesejarahan. Maka dalam penafsirannya dipergunakan metodemetode yang sintesis, yaitu pendekatan ganda (multiple appoarch) (Shiddiqi, 1983: 21). Dengan demikian akan didapatkan kesimpulan yang obyektif karena didasari analisa latar belakang peristiwa yang juga obyektif.

Dalam pengumpulan data penulis menggunakan metode dokumentasi yaitu mencari mengenai hal-hal yang terkait dengan topik masalah dari berbagai literatur baik buku, jurnal ilmiah maupun karya ilmiah lain dari internet yang bisa dipertanggungjawabkan secara ilmiah (Arikunto, 1993: 202).

Data yang terkumpul lalu dianalisis dengan metode gabungan antara metode induktif dan deduktif yang kemudian dipadu dengan metode komparasi, metode yang berusaha untuk mencapai kesimpulan dengan mebandingaka apa yang kita coba untuk membuktikannya denagn sesuatu yang serupa (Bekher, 1990: 65; Hadi 1989: 142). Dengan analisis tersebut diharapkan mampu melahirkan sintesis atau modifikasi ide sehingga diharapkan melahirkan pemikiran baru dan gagasan segara dalam mengurai dan menformulasikan pendidikan Islam berwawasan teologi toleransi beragama menurur para intekektualisme muslim di Indonesia sehingga distingtif daam konteks keindonesiaan.

\section{B. Pembahasan}

\section{Humanisme Religius sebagai Inti Pendidikan Islam}

Agar menemukan konteks body of knowledge dalam kajian ini perlu menelaah ulang perspektif ontologis dan aksiologis dari pendidikan Islam itu sendiri. Tujuanya tidak lain supaya dapat menemukan ruh dalam membangun basis paradigmatik. Untuk itu pada permulaan menjadi penting untuk dikaji terkait humanisme religius sebagai inti dari pendidikan Islam. 
Dalam mengurai pemikiran ulang (rethinking) tentang pendidikan Islam perlu menemukan konsep kunci dalam pendidikan Islam. Salah satu konsep-konsep kunci dalam kosa kata dasar Islam menurut Syed Muhammad Al-Naquib Al-Attas (1996: 34) adalah konsep Pendidikan, yang dalam bahasa Arab dikenal dengan istilah tarbiyah. Namun menururnya istilah tarbiyah bukan istilah yang tepat untuk mendefinisikan pendidikan dalam pengertian Islam, karena hanya menekankan pada aspek fisik dan material dan berwatak kuantitatif.

Yang paling tepat menurut Al-Attas adalah gambaran pendidikan Islam dalam pengertian sebagai ta'dib. Sebab secara struktur konseptual kata ta'dib mencakup proses-proses pengembangan pengetahuan (ilmu), pengajaran ( $t a^{\prime} l i m$ ), dan pengasuhan (tarbiyah). Dapat dikatakan pula kata ta'dib menyangkut ilmu, budaya dan etika. Kata ta'dib adalah masdar dari $a d a b a$ yang berarti pendidikan. Dari kata adaba ini diturunkan pula kata adabun yang menurut Naquib memiliki pengertian:

"Pengenalan dan pengakuan tentang hakekat bahwa pengetahuan dan wujud bersifat teratur secara hirarkis sesuai dengan berbagai tingkat dan derajat tingkatan mereka tentang tempat seseorang yang tepat dalam hubungannya dengan kapasitas dan potensi jasmaniah, intelektual maupun rokhaniyah seseorang" (Al-Attas, 1996: 63).

Sedangkan istilah attarbiyah menurut An-Nahlawi (1995: 20) berasal dari bahasa Arab raba-yarbu yang berarti bertambah dan berkembang. Benang merah yang dapat diambil dari dua pengertian di atas adalah bahwa pendidikan Islam merupakan proses peningkatan atau berkenbangnya potensi yang dimiliki manusia secara dinamis, bukan merupakan sebuah pewarisan budaya atau nilai klasik yang ada sebelumnya. Sehingga pendidikan bukan hanya mengajar namun mencari kebenaran sehingga sumber yang membawa kepada perolehan, ilmiah dan manusiawi dan bukan menjadi suatu romantisisme masa lalu (Hook, 1994: 203). Perkembangan potensi yang diharapkan adalah mengarah kepada dinamisasi yang senantiasa didialogkan dengan individu dan masyarakat yang pluralistik.

Mulkhan juga menegaskan, pendidikan Islam merupakan usaha sadar oleh manusia untuk memberikan peluang bagi 
berkembangnya pengetahuan, kecenderungan, kepribadian atau akhlak (bisa disebut dengan fitrah manusia) (Mulkhan, 1993: 219). Fitrah manusia secara ontologis dapat dikatakan sebagai subyek yang bertindak terhadap dunia dan mengubahnya, dan dengan demikian menuju kemungkinan-kemungkinan yang selalu baru bagi kehidupan yang lebih berkualitas secara peroranagn maupun secara bersama-sama (Freire, 1995: xiii).

Pendidikan Islam disamping mengutamakan proses potensi, menurut HM. Arifin (1991: 10), juga dipentingkan nilai-nilai Islam demi terbentuknya kepribadian muslim. Dalam hal ini pendidikan Islam merupakan sebuah sistem yang dapat memberikan kemampuan seseorang untuk memimpin kehidupannya sesuai dengan cita-cita Islam, sebagaimana nilai-nilai Islam yang telah menjiwai dan mewarnai corak kepribadiannya.

Nilai-nilai yang diajarkan dalam pendidikan Islam adalah nilai yang berdimensi ilahiyah dan insaniyah. Nilai yang pertama, mengajarkan bagaiman hubungan manusia dengan pencipta. Sedangkan nilai insaniyah adalah nilai yang menekanka hubungan dengan sesama dan alam sekitarnya. Nilai-nilai tersebut sangat dibutuhkan bagi tugas manusia terhadap Tuhannya (tugas kekhalifahan) dan tugas manusia untuk memelihara alam sekitarnya atau biasa disebut dengan tugas kekhlifahan.

Dengan mendasarkan berbagai uraian di atas dapatlah dimengerti bahwa pendidikan Islam adalah usaha sadar yang dilakukan manusia melalui suatu proses atau tahapan yang ditunjukkan bagi pengembangan potensi peserta didik didasarkan pada nilai-nilai yang ada dalam Al-Qur'an dan Al-Hadis yang bertujuan membentuk kepribadian Muslim baik yang berdimensi ilahiyah maupun insaniyah.

Dengan dasar pendidikan Islam tersebut akan terbentuk manusia yang berilmu, beriman, dan berbudaya. Maka proses pendidikan didasarkan pada pengembangan fikiran, penataan prilaku, pengaturan emosional, hubungan manusia dengan serta mampu memanfaatkannya hingga memperoleh kebahagiaan hidup (An-Nahlawi (1995: 34). Seluruh ide tersebut telah tergambar secara integratif dalam sebuah konsep yang utuh. Sehingga pendidikan Islam harus didasarkan pada ilmu yang 
berdaya guna. Yakni pendidikan yang didasarkan pada pencapaian ilmu yang berguna bagi pengembangan tugas-tugas kemanusiaan sekaligus mencapai dalam hidupnya. Hal ini mengandung maksud perlunya pemberdayaan ilmu akan tetap eksis untuk menjawab berbagai persoalan yang muncul.

Lebih jauh kalau merujuk pada salah satu ayat Al Qur'an ditegaskan sebagai Akidah transformasi pendidikan Islam disebutkan: "Allah melahirkan kamu kamu dari kandungan ibumu dalam keadaan tidak tau apa-apa lalu. Dia jadikan pendengaran, penglihatan, dan hati nurani, untuk kamu agar kamu mau bersyukur" (QS. An-Nahl:78).

Ayat di atas menurut An-Nahlawi (1995: 34) menegaskan bahwa pendidikan Islam harus memperhatikan potensi indrawi dan juga potensi pikir dan dzikir sehingga mampu mengantarkan generasi bangsa yang bersyukur dan sadar akan jati diriya sebagai hamba dan sekaligus khalifah Allah di bumi. Artinya aspek keimanan dan keyakinan sangat penting untuk dijadikan dasar pendidikan Islam. Karena keimanan dan keyakinan menjadi landasan akidah yang integral dan mengakar serta menjadi motivator yang mencegah manusia untuk berpandanagn ke depan yang lebih optimis, sungguh-sungguh dan berkesadaran. Landasan tersebut dalam rangka memberi inspirasi pada perilaku manusia berdasarkan pemahaman atas tujuan penciptaan manusia- yang berupaya mewujudkan seluruh gambaran, sasaran, norma sesuai perintah Tuhannya.

Pendidikan Islam sangat berperan bagi sarana pengembangan kepribadian manusia agar seluruh aspek dapat teraktualisasi dalam harmoni dan saling menyempurnakan. Ditegaskan oleh Noeng Muhadjir (1987: 76) bahwa setiap manusia (tanpa memandang suatu agama apapun) mempunyai keunggulan, keutamaan dan keistimewaan. Maka supaya interaksi lebih sehat dan lebih dinamis dalam pelaksanaan pendidika diperlukan kesadaran bahwa setiap peserta didik mempunyai kemungkinan, diarahkan, dan dimanfaatkan agar terjadi interaksi yang sehat. Proses tersebut tentunya dilaksanakan dengan dialogis, demokratis dan tanpa ada unsur paksaan dengan dilandasi semangat untuk menerima perbedaan. Inilah yang oleh 
Ki Hadjar Dewantara (1964: 9) disebut sebagai pendidikan yang mampu mengantarkan manusia menjadi merdeka batin, pikiran dan perbuatannya.

Maka pendidikan Islam sebagai suatu sistem sosial dalam hal ini perlu memposisikan Islam sebagai spirit yang dapat memelihara hubungan dengan masyarakat yang pluralistik, yag sejalan dengan perkembangan dan pergeseran yang terjadi di dalamnya. Dari sini akan terjadi proses pendidikan Islam yang berdimensi humanisme. Humanisme menciptakan manusia yang serba bisa, namun selalu dalam perspektif ketuhanan. Humanisme menurut Rusbert sebagaimana dikutip oleh Martin Sardy (1985: 14) membuat manusia sebagai tolok ukur dari segalanya, diperlakukan sebagai subyek otonomi dari proses pendidikan dengan mengedepankan persahabatan, perdamaian dan solidaritas sosial yang bermara pada kesadaran untuk toleransi dalam beragama.

\section{Meneguhkan Tujuan Pendidikan Islam}

Setiap tindakan pendidikan merupakan bagian dari suatu proses menuju kepada tujuan tertentu dengan mempertimbnagkan berbagai macam faktor seperti sejarah, tradisi, kebiasaan, sistem sosial, sistem ekonomi, politik dan kemauan bangsa. Menurut rumusan kongres Pendidikan Islam sedunia tujuan pendidikan Islam adalah:

"Menumbuhkan pola kepribadian manusia yang bulat melalui latihan kejiwaan, kecerdasan otak, penalaran, perasaan dan indera. Pendidikan ini harus melayani pertumbuhan manusia dalam semua aspeknya, baik aspek spiritual, intelektual, imajinasi, jasmani, ilmiah maupun bahasanya (secara perorangan maupun kelompok). Dan pendidikan ini mendorong semua aspek tersebut ke arah keutamaan serta pencapaian kesempurnaan hidup" (Arifin, 1991: 40-41)

Sedangkan menurut Omar Muhammad At-Taumy (1979: 399), konsep tujuan pendidikan Islam harus mampu membawa perubahan yang diingini dan diusahakan oleh proses pendidikan atau usaha pendidikan baik melalui tingkah laku individu pada kehidupan pribadinya atau pada kehidupan masyarakat dan pada alam sekitar tentang hidup individu atau pada proses pendidikan 
sendiri sebagai suatu aktivitas azasi dan proporsi di antara profesi azasi dalam masyarakat.

Rumusan di atas menyadarkan kita bahwa bahwa tujuan pendidikan Islam mencakup tiga setidaknya harus mencakup tiga hal: pertama; Tujuan individual, yaitu berkaitan dengan individuindividu, yakni adanya perubahan yang diinginkan pada tingkah laku, aktifitas, dan persiapan yang diharuskan dalam kehidupan didunia dan akhirat. Kedua; Tujuan sosial, yaitu berkaitan dengan masyarakat secara keseluruhan dengan tingkah laku masyarakat pada umumnya dan dengan apa yang berkaitan denagn kehidupan tentang perubahan yang diinginkan. Ketiga: Tujuan profesional, yaitu berkaitan tentang pendidiakn dan pengajaran sebagai ilmu, seni, profesi, serta aktifitas-aktifitas masyarakat.

Disamping penjabaran tersebut tujuan pendidikan Islam mempertimbnagkan pengalaman dan perkembangan masyarakat atau lingkunag sekitarnya. Hal ini karena dinamika masyarakat cenderung berbuah dengan pesat dan cepat. Sebagiman dirasakan oleh Omar Muhammad At-Taumy (1979: 196) masyarakat Islam merupakan masyarakat yang dinamis, hal ini dapat dilihat dari agama Islam yang banyak menyokong setiap kemajuan dan perubahan yang diperlukan oleh tuntutan perkembangan individu dan masyarakat.

Maka di tengah perubahan sosial pendidikan Islam bukan sekedar menyampaikan tentang ilmu pengetahuan (tarnsfer of knowledge) secara konseptual tetapi juga ilmu pengetahuan tentang kenyataan sosial yang ada serta memberikan kemampuan untuk menilai-kenyataan-kenyataan sosial berdasarkan kriteria yang ditarik dari suatu sistem nilai (transfer if values).

Maka menurut Soedjarmoko (1998: 273) pendidikan Agama (baca: pendidikan Islam) akan memenuhi fungsi yang sangat vital tersebut manakala mampu menanamkan motivasi yang kuat kepada peserta didik untuk menghubungkan nilai-nilai (agama) yang mereka pelajari dengan kenyataan sosial yang ada. Pola-pola itu juga sudah dicontohkan oleh Walisongo khususnya Sunan Kudus dalam mebarkan Islam dengan penuh tepo sliro (toleransi) dan empati (Said, 2013: 37-54). 
Dengan jalan seperti itu, pendidikan Islam dapat memberikan kontribusi bagi pemupukan toleransi beragama dan peningkatan kerja sama antar umat beragama dalam menghadapi masalah-masalah sosial. Dengan demikian peserta didik didorong untuk bersikap kritis dan kreatif dalam menghadapi kenyataankenyataan sosial tersebut dengan didasari seperangkat nilai dan seperangkat norma sebagai pegangan dalam meniti kehidupan yang sangat pluralistis.

\section{Problematika Pendidikan Islam dalam Relasi Keberagamaan}

Tidak bisa dipungkiri bahwa pendidikan Islam sebagai bagian dari sistem pendidikan nasional perlu diposisikan dalam negara kesatuan republik Indonesia yang bhinneka tunggal ika. Maka dalam konteks relasi antar umat beragama masih dijumpai sejumpah persoalan yang perlu mendapatkan perhatian serius dari para praktisi, peneliti dan akademisi. Hal ini setidaknya dapat ditinjau dari segi orientasi atau tujuan, materi, metode maupun evaluasi dalam pendidikan Islam.

\section{a. Kritik Orientasi}

Islam dengan berbagai nuansa normatif yang dibawanya dengan jelas menampakkan orientasi pada suatu universalisme dengan mentransformasikan prinsip rahmatal lil'alamin. Dengan berbagai atribut dan rambu-rambu yang ada, Islam lebih menempatkan diri pada gejala dan kecenderungan humanis, yakni Islam yag mengajarkan dan mendorong umatnya membudayakan persahabatan, perdamaian, dan toleransi dalam beragama (Usa, 1996: 41-42). Kesadaran tersebut seharusnya tercermin pula dalam pendidikan Islam. Tetapi pendidikan Islam yang ada seringkali lebih mengorientasikan pada aspek sektoral-fiqhiyah daripada pengembangan aspek universal-robbaniyyah (Rozikin, dalam Mufid dan Noeh, 1997: 95).

Kesalahan dimaksud adalah terlalu kuatnya tekanan pendidikan Islam pada masalah fiqih, sedangkan kajian terhadap fiqih akan mudah membukakan seseorang pada ikhtilafiyah (perbedaan). Sehingga peserta didik secara langsung telah dikenalkan pada persoalan furu'izyah, sementara doktrin tauhid 
dan implikasi sosialnya kurang mendapat perhatian -untuk tidak mengatakan, ditak diberikan- sebagaimana mestinya, kecuali hanya sebatas menghafal asma'ul husna. Kalaupun diberikan itupun hanya mengarah pada ajaran untuk mengikuti madzhab teologi tertentu, begitu juga yang terjadi dalam fiqih sehingga peserta didik tidak terbiasa dengan perbedaan pendapat. Inilah awal mula tumbuhnya sikap fanatisme secara tidak proporsional (apriori), tanpa didahului penilaian secara kritis.

Produk pendidikan Islam yang demikian tentu bukan yang diharapkan dalam menjalankan peran dan fungsinya sebagai pembawa pencerahan dari kebatilan kepada jalan yang benar (mina al zulumaati ila annuur), pembebasan kelompok-kelompok lemah dan massa tertindas dan pembentukan kembali masyarakat yang bebas dari kepentingan-kepentingan primordialistik termasuk dalam perbedaan keagamaan.

Jika demikian pendidikan Islam harus melakukan reorientasi dari sekedar berorientasi sektor fiqhiyyah, kepada penekanan aspek universal-robbaniyyah. Yang pertama menundukkan realitas kepada kebenaran fiqih dan berwatak hitam putih dalam memandang realitas itu (Baso, 1997: 137). Sementara Islam sendiri sarat dengan nilai-nilai universal yang bisa mengayomi semuat umat semesta alam. Nilai-nilai universal itu misalnya dalam keadilan (al-ta'aadul), egalitarianisme (al-musawah), toleransi (al tasamuh), moderat (al tawasuth), kemanusiaan (al basyariyyah), demokrasi (asy-syura), keseimbangan (al tawazun), solidaritas sosial (altakaful al-ijtima'i), dan lain-lain.

\section{b. Kritik Materi}

Pada dasarnya dalam pendidikan Islam merupakan sekumpulan nilai yang terangkum dalam Al Qur'an, Hadis dan Syariat yang didasarkan pada penafsiran dan pemahaman ulama' atau kyai yang kompeten. Namun masih sering dijumpai suatu penafsiran atau pemahaman terhadap teks-teks suci yang menjadi materi pendidikan Islam yang seringkali memicu ketegangan bahkan mmenyuburkan sistem-sistem hukum dan budaya yang saling menyingkirkan, sehingga menghambat tumbuhnya budaya toleransi beragama dalam kompleksitas kehidupan keberagamaan. 
Seperti disampaikan oleh Arkoun bahwa:

"Konsep toleran merupakan prestasi modern yang tidak dapat dipisahkan dari kritik filosofis terhadap kebenaran. Umat Islam, seperti halnya orang-orang Kristen berangkat dari klaim terhadap kebenaran wahyu sebagai landasan bagi legislasi kebenaran wahyu yang unik mutlak tidak dapat dirubah, di luar historisitas, dipahami dan secara benar dibawa hanya oleh orang-orang yang menyatakan keimanan mereka semua kepada semua dogma yang membentuk kebenaran ini. Orang-orang Yahudi dan orang-orang Kristen menolak untuk mengaku dogma utama Islam Al Qur'an sebagai firman Tuhan, yang diwahyukan kepada umat manusia melalui perantaraan Muhammad, Rasul-Nya. Orang-orang Yahudi juga melakukan halnya yang sama terhadap orang-orang kristen, yang juga melakukannya terhadap orang-orang Yahudi dan orang-orang Islam. Dalam definisi tentang kebenaran ini, orang hanya dapat membangun teologi-teologi dan tatanan-tatanan sosiopolitik yang berfungsi sebagai sistem-sistem hukum dan budaya yang saling menyingkirkan" (Arkoun, 1996: 87).

Dari kutipan di atas dapat dipahami, bahwa telah terjadi timbal balik pemahaman terhadap filosofis kebenaran wahyu bagi oarng-orang Yahudi, Kristen maupun orang-orang Islam yang "saling menyingkirka satu sama lain". Jika demikian, ide toleransi beragama secara perlahan mengalami kesulitan besar dalam bentuk yang selalu berbahaya melalui ekses-ekses dari konflik dan ketegangan antar agama, yang orang-orang Barat sering menyebut perang agama. Kenyataan ini selanjutnya mengaburkan etika sosial dalam membangun relasi dan penegakan hak-hak / kewajiban bagi umat manusia dalam masyarakat dengan linatas agama, yang semestinya secara teologis Islam dengan nilai-nilai keuniversalannya telah memberikan garis bagaimana harus berinteraksi denagn kelompok non-moslem.

Lebih memprihatinkan lagi Nurcholis Madjid (1997: 141) mensinyalir bahwa lembaga-lembaga pendidikan agama (Islam) baik di sekolah maupun madrasah dari tingkat paling bawah sampai tingkat tinggi umumnya didominasi oleh materi pelajaran yang berorientasi Fiqh dan Kalam, yang tak lain adalah segi-segi eksoteris atau furuiyyah dari agama itu sendiri. Hal ini menjadikan peserta didik lebih paham misalnya tentang syarat dan rukun bagi syah atau tidaknya sholat, dari pada mengetahui apa sesungguhnya 
makna dari sholat itu bagi pembentukan diri pribadinya baik lahir maupun bathin. Dan karena dominasi kalam, menurut Nurcholis Madjid, mereka akan lebih mampu misalnya, bagaiman membuktikan Allah itu ada tanpa memiliki keinsyafan apa makna yang paling dalam adanya kehadiran Tuhan dalam kehidupan.

Padahal dalam filsafat perenial dalam relasi antara agama setidaknya dapat ditemukan kesatuan transenden agama-agama, sehubungan dengan realitas metafisik bahwa hanya tuhan-lah sebagai peringkat tertinggi dimana semua agama akan bertemu sebagai wilayah "jantung"nya agama-agama yang tak lain semua itu hanya berada pada tingkat esoteris, transeden dan substansi (Schoun, 1987). Perbedaan-perbedaan antara agama yang satu dengan agama yang lain akan semakin mengecil dan bersatu pada tingkat yang tertinggi (esoteris), sebaliknya di tingkat bawahnya (eksoteris) berbagai agama akan memperbesar ruang perbedaan.

Kalau keseimbangan materi pelajaran dalam pendidikan Islam yang berdimensi eksoteris berupa fiqhiyyah dan esoteris (etik-sufistik) tidak imbang dan berlangsung secara terus menerus, kehidupan umat beragama yang ramah, toleran dan penuh kebersamaan akan sulit terlaksana. Karena semua justru mensyaratkan adanya wawasan esoteris (substansial) agamaagama yang mewadahi, dalam kehidupan umat beragama.

Keprihatinan Nurcholis Madjid tentang terlalu dominannya materi dalam pendidikan Islam yang cenderung menekan segisegi eksoteris dalam kehidupan keberagamaan mengindikasikan bahwa telah terjadi sebuah proses semacam "pendangkalan" dalam memaknai agama (Islam) yang telah mereduksi nilai-nilai universalitas Islam itu sendiri. Yang lebih menyayat hati gejala ini antara lain terjadi secara terlembaga - baik iti disadari atau tidak antara lain melalui berbagai lembaga pendidikan.

Yang memprihatinkan dalam riset atas buku ajar PAI yang dilakukan di Jombang, Bandung, Depok, dan Jakarta menemukan sejumlah buku ajar keislaman di sekolah memuat dorongan intoleransi, bahkan mengajarkan kekerasan. Buku-buku ajar ini mengarahkan pada penyesatan atas praktik-praktik keagaman tertentu seperti ziarah kubur dan tahlilan. Beberapa konsep sensitif seperti kafir, musyrik, dan khilafah juga dibiarkan tanpa klarifikasi 
mendalam. Selain itu, beberapa buku teks ditemukan memuat ditemukan material yang tidak cukup akomodatif atas perbedaan faham dalam Islam. Diantaranya seperti penegasan pelaksanaan syariah yang mensyaratkan khilafah dan demokrasi sebagai syirik. Padahal dalam konteks kebangsaan dan keindonesiaan, hal ini bisa disampaikan, bahwa pengamalan Pancasila juga pada hakikatnya pengamalan Islam (Azra, 2015).

Sementara dalam kesimpulan atas survei yang dilakukan lembaga studi Center of Strategic and International Studies (CSIS) menunjukkan bahwa toleransi beragama orang Indonesia masih rendah. Indikasinya bisa dilihat dalam dilihat antara lain dari penolakan pembangunan tempat ibadah. Mayoritas orang Indonesia bisa menerima tetangga yang beda agama, namun tidak bisa menerima jika ada pembangunan tempat ibadah agama lain di sekitar lingkungannya. Lembaga studi CSIS sudah melakukan survei pada Februari di 23 provinsi Indonesia. Dari 23 provinsi tersebut ada 2.213 responden. Survei dilakukan dengan cara mengajukan pertanyaan yang ada hubungannya dengan toleransi beragama. Hasilnya, sebanyak 59,5 persen responden tidak keberatan bertetangga dengan orang yang beda agama. Sedagkan 33,7 persen lainnya memilih menolak tetangga yang beda agama dengan mereka. Kemudian survei beralih ke pertanyaan soal pembangunan rumah ibadah agama lain di sekitar lingkungan mereka. Sebanyak 68,2 persen responden memilih menolak pembangunan tersebut. Sementara 22,1 persen lainnya mengaku tidak berkeberatan.

Sedikitnya porsi bahasan mengenai toleransi beragama dan terdapatnya materi PAI yang menunjukkan adanya intoleransi menandakan betapa pendidikan Islam dalam perspektif ini kurang mendapat perhatian yang semestinya. Sementara dalam visi New Age - cara hidup New Age ditandai dengan besarnya arus mencari model-model kearifan (tradisional) Timur, yang dirasakan sangat diperlukan dalm mengatasi bebagai krisis sosial masyarakat. Berbagai krisis sosial masyarakat diyakini berakar dari pengertian yang salah dan ketidaktahuan tentang hakekat diri (The Self) dengan alam kosmis. Adanya hubungan hakekat diri (the Self) dengan "Yang Kosmis" merupakan dasar dari pandanagn- 
pandanagn New Age - manusia modern sekarang ini tidak tahu lagi bagaimana berhubungan dengan Tuhan, dengan sesama manusia dan dengan alam secara tepat (Rohman, 1996: 48-49).

Agama-agama yang terorganisasi tidak dihargai lagi, sehingga Erich Fromm seperti dikutip oleh Rohman (1996: 49) menilainya terlalu "otoriter" terhadap manusia konkert. Dalam konteks inilah kalangan New Age menyetujui pandangan Erich Fromm bahwa manusia modern memerlukan agama yang "humanistik" yang tentunya nilai-nilai tersebut dikembangkan dalam teologi toleransi beragama.

Uraian di atas mengindikasikan betapa telah terjadi proses pendangkalan materi dalam pendidikan Islam yang cenderung telah mengabaikan --untuk tidak mengatakan menyembunyikannilai-nilai sebstantif (esoteris), yang justru lebih dibutuhkan dalam penembagan kehidupan keagamaan yag inklusif, toleran dan respek terhadap pluralisme keagamaan terutama dalam memenuhi tantanagn New Age.

\section{c. Kritik Metode}

Elemen penting dalam pendidikan Islam adalah motode. Menurut Amin Abdullah (1996: 66) materi PAI di sekolah dan praksis pendidikan Islam di madrasah cenderung menggunakan metode monologis. Dengan metode ini pendidik dapat leluasa melakukan indoktrinasi-indoktrinasi terhadap peserta didik. Metode ini secara tidak sadar telah mematikan kreatifitas dan daya kritis pesreta didik untuk mengetahui secara mendalam dengan pernyataan-pernyataan kritis. Karena pendidikan indoktrinasi memaksakan nilai-nilai yang sudah dianggap baku, dengan demikian pendidikan Isalm tidak melihat peserta didik nilai tersendiri, berkepribadian yang unik dengan status bermartabat sebagai manusia yang harus dihormati.

Sebagai akibat berikutnya pesert didik hanya akan memperoleh pemahaman ajaran keagamaan yang parsial (sepotong-Sepotong) karena proses pembelajaran yang tidak mendukung adanya dialog yang sesungguhnya. Lantaran pengaruh pemahaman keagamaan yang parsial inilah, menurut Amin Abdullah (1996: 66-67), selanjutnya menggumpal dalam lapisan geologi pemikiran keagamaan, sehingga moral 
kenabian Islam yang aturannya bersifat universal, inklusif, hanif, tereduksi sedemikian rupa sehingga seolah-olah menjadi sematamata "ekslusif", "Patrikularistik", "legalistik-formalistik dan ahistoris" sehingga untuk wilayah dan era tertentu dalam sejarah peradaban Islam terjadi proses distorsi nilai-nilai etika Islam yang menjadikannya begitu sempit-menjerat.

Proses monologis ini juga akan mengakibatkan kemandegan dalam pengembangan nilai-nilai Islam sebagai sistem nilai dalam menjalani kehidupan yang humanis. Pendidikan Isalam akhirnya mengalami apa yang disebut Freire (1999: 11) sebagai antagonisme pendidikan "gaya bank" dengan kecenderungan: guru mengajar, murid belajar, guru tahu segalanya, murid dianggap tidak tahu apa-apa, guru berpikir, murid dipikirkan, guru berbicara murid mendengarkan, guru adalah subyek proses belajar dan murid sebagai subyek belaka.

Implikasi yang lebih jauh adalah pada saatnya peserta didik menjadikan diri mereka sebagai duplikasi guru/ustadz/ kyai mereka, pada saat itulah pada saat tertentu karena metode pembelajaran yang monologis akan lahir generasi baru manusiamanusia penindas. Apabila diantara mereka ada yang menjadi pendidik agama Islam, maka dua penindasan segera dimulai dalam dunia pendidikan Islam, dan demikian terjadi seterusnya.model pendidikan, karena itu, hanya sekedar menjadi saran terbaik untuk melestarikan kelangsungan suatu teologi tertentu, bukan menjadi kekuatan penggugahan kearah perubahan dan pembaharuan.

Selanjutnya pendidikan Islam akan mengalami seperti degradasi atau meminjam istilah Mokhtar Bukhori (1994: 27) sekedar menjadi "pengajaran" bukan "pendidikan". Mendidik paling tidak merupakan upaya untuk mengembangkan pandangan hidup, sikap hidup, dan ketrampilan hidup pada diri seseorang atau sekelompok orang. Karena sifatnya sekedar pengajaran maka pendidikan Islam adalah formal pengajaran yang hanya sekedar mentransfer pengetahuan (transfer of knowledge), bukan upaya memperoleh pengetahuan yang menjadi proses transformasi yang diuju dalam kehidupan nyata, Paulo Freire (1999: 76) menyebutnya sebagai pendidikan yang menindas. Bagi Freire, 
penindasan apapun nama dana alasannya adalah tidak manusiawi, sesuatu yag meniadakan hakekat kemanusiaan (dehumanisasi).

Jika demikian peserta didik akan menjadi manusia-manusia yang terasingkan dan tercabut dari realitas sekitarnya, karena mereka "menjadi ada" dalam pengertian "menjadi seperti" orang lain, bukan menjadi dirinya sendiri lantaran dikondisikan oleh kebudayaan bisu itu sendiri. Dalam bahasa Ki Hadjar Dewantara (1964: 22) peserta didik lalu tidak merdeka secara pikiran, perasaan dan tindakannya. Padahal pengetahuan apapun termasuk pengetahuan agama Islam harus memberi manfaat secara lahir maupun batin. Kalau ini terjadi maka pendidikan Islam hanya sekedar proses penguasaan (dominasi) atau penjinakan teologis bukan pemerdekaan atau pencerahan, yang cenderung membawa anak kepada teologi tertentu secara taken for granted dan hitam putih tanpa dilandasi proses penyadaran (konsistensi) kritis. Peserta didik akan menjadi individu yang eksklusif tidak mau mengakui adanya kebenaran di kelompok lain.

Implikasi praktisnya dalam beragama adalah mereka tidak akan menerima/memahami adanya kompleksitas keberagamaan yang ada, maka akan hilanglah kesadaran pereneal yang mampu menjadi perekat bagi kesatuan transenden agama-agama. Ini tentunya sangat membahayakan bagi terbangunnya budaya toleransi beragama sebagai salah satu prinsip penting yang dikembagkan dalam keuniversalan Islam. Dengan demikian nampaklah bahwa pendidikan Islam dalam aspek-aspek tertentu memiliki peran cukup strategis bagi upaya pembudayaan dan pengembangan teologi toleransi beragama kepada peserta didik dalam arti luas.

\section{d. Kritik Evaluasi}

Salah satu elemen pendidikan Islam yang tidak boleh diabaikan adalah evaluasi. Kecenderungan evaluasi kurang mendapatkan ruang yang mumpuni dalam pendidikan Islam sebagai dampak dari kaburnya tujuan dalam pendidikan Islam. Semakin tidak jelas formulasi tujuan dalam pendidikan Islam, maka semakin sulit untuk melakukan evaluasi. Demikian juga sebaliknya semakin jelas dalam merumuskan tujuan pendidikan maka akan semakin mudah dalam melakukan proses evaluasi. 
Bapak Pendidikan Nasional kita, Ki Hajar Dewantara (1964: 25) memiliki taksonomi khas nusantara sebagai ranah evaluasi dalam pendidikan termasuk dalam pendidikan Islam yaitu itu Ngerti, Ngrasa dan Ngalakoni. Beliau menegaskan: "Djangan hanja mengerti, Djangan pula tjukup merasai dalam arti "membenarkan", namun seharusnjalah kita melakukan apa jang sudah dibenarkan dan dianggap baik oleh akal budi"

Taksonomi pendidikan ala Ki Hajar Dewantara yang meliputi Ngerti, Ngrasa dan Ngalakoni ini selaras dengan konsep iman dalam Islam. Sebagaimana sudah populer dikenal iman tak cukup hanya diucapkan (diiqrarkan), tapi harus dibenarkan dalam hati (tasdiqun bi al qalb), dan dimalkan dengan perbuatan nyata (wa 'amalun bi al arkan). Maka pendidikan toleransi beragama dalam Islam tak cukup hanya berhenti di tingkat mengerti, tapi juga menyentuh dalam hati hingga ngrasa (membenarkan) yang buahnya adalah nglakoni, menjadi probadi yang toleran dalam kehidupan lintas agama dan budaya.

\section{Universalisme Islam sebagai Inti Pendidikan Islam}

Menurut Alwi Shihab (1999: 35-36) pendidikan mempunyai peran yang penting bagi para pemimpin masyarakat dan para pengikutnya bukan saja untuk memahami orang lain tetapi juga menagkap makna hidup dan bagaimana berinteraksi positif dengan orang lain sebagai orang yang beriman dengan wawasan yang lebih terbuka dalam kerangka mendirikan dan menumbuhkan budaya toleransi beragama. Peranan pendidikan -pengakuan akan pentingnya peran pendidikan dalam membangun peradaban Islam yang lebih tinggi diakui juga oleh Isma'il Raji Al Faruqi (1995: 21), namun banyak agenda persoalan dalam pendidikan Islam juga disadarai sebagai tugas berat dalam abad ini yang harus segera dipecahkan tersebut tidak akan terwujud apabila masih ada berbagai ketimpanagan dan persoalan antara lain terkait dengan orientasi, materi, metode dan juga evaluasi dalam pendidikan Islam sebagaimana telah diuraikan di atas belum terpecahkan secara tuntas.

Ketimpangan yang terdapat dalam orientasi pendidikan Islam misalnya yang lebih menekankan aspek sektoral-fiqhiyyah 
daripada pengembangan aspek universal-robbaniyyah, sementara doktrin Tauhid dan implikasi sosialnya tidak diberikan kepada peerta didik, yang pada gilirannya akan memperlebar ruang perbedaan (ikhtilafiyah). Gejala ini bisa jadi merupakan awal tumbuhnya sikap fanatisme agama dalam beragama. Islam adalah agama toleransi, mengajarkan umatnya untuk saling memahami/ saling mengerti (mutual understansing) dengan pengikut agama lain. Islam menghindari sikap ta'as $>s>u b$ (fanatisme golongan yang tercela), serta menghindari pemaksaan dalam beragama terhadap orang lain) (Al-Djamali, 1983: 18-19). Persoalannya terletak pada kesepakatan bersama dalam jalur perbuatan yang menentukan titik keberangkatannya. Dalam hal ini yang berprofesi dalam kependidikan dan pengajaran, maka melihat awal problemnya terletak pada masalah kependidikan.

Oleh karenanya sudah saatnya memberikan pendidikan Islam yang berorientasi pada pendidikan toleransi dan kerukunanumat beragama sungguh-sungguh diperhatikan secara serius, karena hal itu sebagai bagian dari universalisme Islam yang dibawa oleh Rasulullah SAW. Sedangkan dalam toleransi beragama Alwi Shihab (Shihab, 1999: 41) mensyaratkan adanya sikap pluralisme. Dalam pluralisme tidak cukup hanya dengan sikap mengakui dan menerima kenyataan bahwa masyarakat itu bersifat majmuk, beraneka ragam, terdiri atas berbagai suku, bangsa dan agama yang justru menggambarkan fragmatisme.

Pluralisme juga tidak boleh dipahami sebagai kebaikan "kebaikan negatif" (negative good) sekedar ditilik dari kegunaannya untuk menyingkirkan fanatisme (to keep fanatism at bay), yang justru menggambarkan kesan pragmatisme (Nurcholis Madjid, 1999). Namun yag dimaksud adalah adanya keterlibatan aktif terhadap kenyataan kemajmukan tersebut, sehingga pluralisme agama adalah tiap pemeluk agama dituntut bukan hanya mengakui keberadaaan dan hak agama lain, tetapi terlibat dalam usaha memahami perbedaan dan persamaan guna terciptanya kerukunan dalam kebinekaan (Shihab, 1999: 41).

Senada dengan Alwi Shihab, Nurcholis Madjid (1999) menegaskan bahwa pluralisme harus dipahami sebagai 'pertalian sejati kebinnekaan dalam ikatan-ikatan keadaban’ (genuine 
engagement of diversities within the bon of civility). Dan pluralisme merupakan suatu keharusan bagi umat keselamatan umat manusia. Karena itu renungan tentang pendidikan yang berorientasi toleransi beragama sebenarnya adalah muncul secara logis sebagai kelanjutan dari renungan tentang toleransi beragama. Karena toleransi beragama mensyaratkan adanya sikap pluralisme seperti yang dimaksud di atas, maka pendidikan toleransi beragama Tidak terbatas pada pengajaran tentang bagaimana membudayakan sikap membiarkan orang lain hidup di sekitar kita tanpa larangan dan penganiayaan, tetapi juga menuntut adanya keterlibatan aktif dalam kemajmukan itu dilandasi semangat menjunjung tinggi nilai-nilai universalitas Islam dan adanya kesatuan transenden dalam agama-agama.

Untuk kepentingan semua itu jelaslah bahwa materi pendidikan Isalm tidak cukup dengan hanya sebatas pengajaran tentang ritus-ritus keagamaan dan segi-segi formalistiknya belaka, yang bersifat eksoterik, justru yag lebih penting adalah seberapa jauh tertanam nilai-nilai keagamaan itu terwujud nyata dalam tingkah laku dan budi pekertinya sehari-hari, yang kemudian melahirkan solidaritas dan budi luhur (akhlakul karimah).

Nilai-nilai moral yang bersifat esoterik seperti persaudaraan, persamaan, keadilan, berbaik sangka, rendah hati, menepat janji, dapat dipercaya, kewiraan, sederhana dan tidak boros, dan dermawanan sosial itu perlu disemaikan melalui pendidikan Islam di berbagai jenjang. Karena pendidikan Islam adalah sarat dengan sistem nilai, maka sudah sepatutnya dilakukan dengan kolaborasi antara pihak sekolah, orang tua dan masyarakat (Said, 2015: 57-77).

Maka Nurcholis Madjid mengkritik habis-habisan terhadap berbagai lembaga pendidikan yang cenderung menekankan materi pelajaran yang dalam segi eksoterisnya saja. Adanya pendidikan Islam yang lebih mengedepankan segi-segi ritual dan formal keagamaan adalah sebuah indikator yang memperkuat penilaian Cak Nur di atas. Padahal perbuatan ritual keagamaan (seperi ibadah) adalah gambar-gambar lahiriah, sedangkan jiwa (ruh) amal perbuatan itu adalah adanya "rahasia keikhlasan" 
di dalamnya. Fenomena inilah yang disebut Nurcholis Madjid (1997: 126, 143) sebagai "gejala pendangkalan agama".

Maka, sudah saatnya lebih-lebih dalam memasuki abad ke-21 ini, dimana secara romantis banyak kalangan menilai sebagai "kebangkitan millinium ketiga" dan Naisbitt (1989: 59) menilainya bakal terjadi "kebangkitan rasa keagamaan" secara global-,pendidikan Islam mengembalikan peran dan fungsinya secara progresif sebagai perekat kehidupan umat beragama dalam menjalankan peran dan fungsi spirit Islam sebagai rahmatan lil'alamin.

\section{Simpulan}

Dari uraian di atas dapat dijelaskan beberapa kesimpulan bahwa proses pendidikan Islam sebagai bagian dari sistem sosial perlu memposisikan Islam sebagai landasan falsafahnya sehingga mampu memelihara hubungan dengan masyarakat yang pluralistik. Dari sini akan terjadi proses pendidikan Islam yang berdimensi humanisme. Humanisme menciptakan manusia yang serba bisa dibalut dengan kecerdasan empatik sebagai spirit cinta (rahmän-rahim) dalam perspektif ketuhanan.

Problematikan pendidikan Islam dalam perspektif humanisme Islam menunjukkan setidaknya bisa ditelaah dari empat aspek yaitu sisi orientasi atau tujuan, materi, metode maupun evaluasi. Dari segi orientasi pendidikan Islam di Indonesia masih menonjolkan aspek sektoral-fiqhiyah daripada pengembangan aspek universal-robbaniyyah. Hal ini berakibat materi pendidikan Islam cenderung didominasi oleh materi fiqh daripada pengambangan akhlak mulai semacam nilai-nilai toleransi beragama. Lebih memprihatinkan lagi kecenderungan pendidikan dari sisi metode lebih bersifat monologis sehingga kritisisme menjadi minim. Sementara dari sisi evaluasi meminjam taksonomi Ki Hajar Dewantara cenderung menekankan evaluasi aspekngerti (memahamai), sementara aspek ngrasa (membenarkan dan mencintai) nilai yang dipahami kurang tersentuh sehingga aspek nglakoni menjadi mentah.

Dalam meneguhkan pendidikan toleransi beragama dalam Islam penting kiranya menentukan nilai-nilai inti (corevalues) yang 
perlu dijadikan materi inti dalam pendidikan dalam tiga ranah sekaligus yakni ngerti, ngrasa dan nglakoni. Nilai-nilai inti tersebut seperti persaudaraan, persamaan, keadilan, berbaik sangka, rendah hati, menepat janji, dapat dipercaya, kewiraan, sederhana dan tidak boros, dan dermawanan sosial. Pendidikan Islam sarat dengan nilai, maka pendidikan nilai tidak cukup diajarkan di kelas tetapi perlu berkolaborasi dengan institusi terkait seperti keluarga dan lingkungan sosial terdekat sehingga bersatu padu nilai-nilai itu menjadi hidup dalam realitas nyata. 


\section{DAFTAR PUSTAKA}

Arkoun, Muhammad, 1995, Rethinking Islam, (Yogyakarta, Pustaka Pelajar)

Azra, Azyumardi, 1999, Konteks Berteologi di Indonesia Pengalaman Islam, (Jakarta, Paramadina,)

Bukhori, Mochtar, 1994, Ilmu Pendidikan dan Praktek Pendidikan dalam Renungan, (Jakarta IKIP Muhammadiyah Jakarta Press,)

Bukhori, Mochtar, 1994, Pendidikan Agama, Perkembangan Ilmu dan Teknologi Serta Perubahan Sosial, dalam, spektrum Problem Pendidikan di Indonesia, Tiara Wacana, Yogyakarta,,

Casanova, Jove, 1994. Public Religion in the Modern World, (New York, The University of Chicago Press).

Efendi, Djohan \& Hadi Abdul, W.M,. 1986. Iqbal Pemikir Sosial Islam dan Sajak-sajaknya, (Jakarta,; PT. Pantja Simpati,)

Efendi, Djohan, Kehidupan Umat Beragama Dalam Cita-Cita Gus Dur, Harian Umum Kompas, 26 Nopember 1996

Freire, Paulo, 1995, Pendidikan Kaum Tertindas, (Jakarta,: LP3ES),

Hook, Sidney, 1994, Sidhey Hook: Sosok Filusuf Humanis Demokrat dalam Tradisi Pragmatisme, Jakarta, Yayasan Obor,)

Ismail, Faisal, 2015. Dinamika Kerukunan Antar Umat Beragama, (Bandung: Rosdakarya

Kuntowijoyo, 1991, Paradigma Islam: Interpretasi untuk Aksi, (Bandung, Mizan,)

Madjid, Nur Cholis, 1995, Islam agama Kemanusiaan, (Paramadina, Jakarta)

Madjid, Nurcholis, 1992, Islam, Doktrin dan Peradaban: Sebuah Telaah Kritis Tentang Masalah keimanan, Kemanusiaan, dan kemodernan, cet. Ke-1 (Jakarta, Yayasan wakaf Paramadina) 
Mulkhan, Abdul Munir, 1993, Paradidma Intelektual Moslem, (Sipress, Yogyakarta,)

Rohman, Fazlur, 1996, Islam dan Modernitas, Tentang Transformasi Intelektual, (Bandung; Pustaka)

Said, Nur, 2005. Perempuan dalam Himpitan Teologi dan HAM di Indonesia, (Yogyakarta: Pilar Media, 2005).

Schoun, Fithjof, The Transcendent Unity Of Religions, terj. Safaroedin Bahar, 1987, Mencari Titik Temu Agama-agama, (Jakarta, Yayasan obor Indonesia,)

Shihab, Alwi, 1998, Islam Inklusif Menuju Sikap Terbuka Dalam Beragama Bandung. Mizan,

Shihab, Quraish, 1996, Membumikan Al Qur'an, Bandung. Mizan, Cet.IV.

Soejatmoko, 1988, Pengaruh Pendidikan Agama Terhadap Kehidupam Sosial, dalam Etika Pembebasan, Jakarta. LP3ES, 
